\title{
Pengaruh Literasi Keuangan dan Sikap terhadap Uang pada Pengelolaan Keuangan Keluarga
}

The Effect of Financial Literation and Attitude to Money on Family Financial Management

\author{
Sri Mulyati ${ }^{1}$, Ravika Permata Hati ${ }^{2}$ \\ Universitas Riau Kepulauan, Batam ${ }^{1,2}$ \\ sri@fekon.unrika.ac.id 11
}

\begin{abstract}
ABSTRAK
Tujuan dari penelitian ini adalah untuk menguji dan menganalisis dampak literasi keuangan dan sikap terhadap uang pada perencanaan keuangan keluarga.Penelitian ini menggunakan data kuantitatif. Populasi penelitian ini meliputi masyarakat yang berdomisili pada Kecamatan Sekupang.Teknik pengambilan sampel yang digunakan purpose sampling berdasarkan pendapatan atau penghasilan keluarga dengan nominal minimal Rp. 3.500.000,-. Dalam penelitian ini melibatkan 200 responden. Metode pengumpulan data menggunakan kusioner dan metode analisis data menggunakan alat analisis SPSS 20. Hasil Penelitian ini akan menunjukkan bagaimana pengaruh literasi keuangan dan sikap terhadap uang pada pengelolaan keuangan keluarga di lingkungan masyarakat Kecamatan Sekupang

Kata Kunci : Literasi Keuangan, Sikap Terhadap Uang, Perencanaan Keuangan
\end{abstract}

\begin{abstract}
The purpose of this study was to examine and analyze the impact of financial literacy and attitudes towards money on family financial planning. This study uses quantitative data. The population of this study includes people who live in Sekupang District. The sampling technique used is purposive sampling based on family income or income with a minimum nominal value of Rp. 3,500,000, -- This study involved 200 respondents. The data collection method used questionnaires and data analysis methods used the SPSS 20 analysis tool. The results of this study will show how the influence of financial literacy and attitudes towards money on family financial management in the Sekupang District community.

Keywords: Financial Literacy, Attitudes Toward Money, Financial Planning
\end{abstract}

\section{PENDAHULUAN}

Pada tahun 2020 ini, dunia diguncangkan dengan merebaknya wabah virus corona atau Covid -19 membuat banyak orang berfikir ulang mengenai pengelolaan keuangan pribadi. Terlebih bagi mereka yang sudah berkeluarga dan dengan penghasilan rata - rata. Tidak jarang pendapatan masyarakat mulai berkurang akibat virus corona. Menurut Prita (2020) yang merupakan direktur ZAP Finance, menyebutkan bahwa dampak lansung dari situasi kritis seperti ini adalah keuangan yang berpotensi menjadi tidak sehat.

Perencanaan keuangan keluarga merupakan salah satu bentuk dari manajemen keuangan. Salah satu komponen dalam melakukan perencanaan keuangan adalah menyusun anggaran setiap bulan yang terdiri dari pendapatan yang diperoleh dan pengeluaran. Pada pengeluaran keuangan dalam masyarakat, tiap bulannya banyak pengeluaran diluar dugaan yang di perkirakan oleh setiap keluarga, sehingga ketika terjadi hal yang tidak diharapkan kebanyakan keluarga kebingungan karena keuangan untuk hal tersebut tidak tersedia.

Menurut Subiaktono (2013) langkah- langkah awal dari perencanaan keuangan adalah mempelajari kondisi keuangan pribadi yaitu dengan melihat pemasukan, pengeluaran, serta mengenali 
instrumen- instrumen investasi yang akan dipilih, menentukan tujuan apa yang diinginkan masing masing pribadi, mengenali suatu pola investasi yang akan dimasuki. Menurut Masassya (2007), mengartikan perencanaan keuangan keluarga merupakan strategi bagaimana keluarga dapat mencapai tujuan keuangan keluarga dalam jangka pendek, menengah, dan panjang.

Menurut Vincentius dan Nanik Linawati (2014), Literasi keuangan dengan perencanaan keuangan keluarga ini berpengaruh yang positif, semakin tinggi atau semakin baik literasi keuangan yang dimiliki oleh individu maka akan semakin baik perilaku perencanaan keuangan. Begitu sebaliknya, semakin rendah atau semakin buruk literasi keuangan yang dimiliki oleh individu maka akan berpengaruh negatif pada perilaku perencanaan keuangannya yang juga semakin memburuk. Dengan kata lain, individu yang memiliki tingkat literasi keuangan yang baik akan mudah untuk memahami perencanaan keuangan yang baik dan benar, selain itu individu tersebut juga memiliki kemampuan dan kepercayaan diri dalam mengambil keputusan keuangan.

Menurut Norma dan Meliza (2013) orang yang memiliki pengetahuan keuangan yang lebih baik akan memiliki perilaku keuangan seperti membayar semua tagihannya tepat waktu, membukukan pengeluaran setiap bulan dan memiliki dana darurat. Namun pernyataan tersebut berbanding terbalik dengan penelitian yang dilakukan oleh Irine dan Lady (2016) yang menyimpulkan bahwa financial knowledge tidak berpengaruh terhadap financial management behavioral, karena tidak selamanya individu yang pengetahuan keuangan yang tinggi selalu dapat mengendalikan keuangannya atau literasi keuangan tidak memiliki pengaruh terhadap perilaku pengelolaan keuangan individu yang dimiliki karena literasi keuangan menggambarkan adanya pendidikan keuangan individu tersebut.

Sikap terhadap uang juga menjadi salah satu faktor yang dapat mempengaruhi perencanaan keuangan keluarga. Dalam penelitian yang dilakukan oleh Silvi (2013) penelitian ini memiliki tujuan untuk menguji apakah pengetahuan keuangan dan pengalaman sebagai ukuran literasi yang mempengaruhi sikap dan perilaku perencanaan investasi perencanaan keuangan keluarga di Surabaya. Hasil dari penelitian ini menunjukan bahwa pengetahuan keuangan dan pengalaman keuangan mempengaruhi perilaku perencanaan investasi keuangan keluarga, sikap pengelola keuangan memoderasi dan memperkuat pengaruh pengetahuan keuangan dan tidak memoderasi pengaruh pengalaman keuangan terhadap perilaku perencanaan investasi keuangankeluarga. Menurut Shohib (2015) sikap terhadap uang mampu mempengaruhi perilaku keuangan sehari-hari, sikap mampu mempengaruhi rencana menabung dan sikap mempengaruhi kemampuan keuangan masa depan. Menurut Ririn Nindia dan Hartoyo (2013) bahwa sikap terhadap uang berpengaruh positif signifikan pada perencanaan keuangan keluarga. Berdasarkan uraian diatas banyak faktor yang bisa mempengaruhi perencanaan keuangan keluarga dan banyak penelitian terdahulu yang sudah menggunakan variabel ini, sehingga peneliti tertarik untuk mengembangkan variabel tersebut dan melakukan penelitian di Kota Batam dengan mengambil judul "PENGARUH LITERASI KEUANGAN DAN SIKAP TERHADAP UANG PADA PENGELOLAAN KEUANGAN KELUARGA MASYARAKAT KECAMATAN SEKUPANG"

\section{LANDASAN TEORI}

Literasi Keuangan

Menurut lembaga Otoritas Jasa Keuangan (2013) menyatakan bahwa secara definisi literasi diartikan sebagai kemapuan memahami. Jadi literasi keuangan adalah kemampuan mengelola dana yang dimiliki agar berkembang dan hidup bisa lebih sejahtera dimasa yang akan datang OJK mengatakan bahwa hal penting dari program literasi keuangan adalah untuk melakukan edukasi di bidang keuangan kepada masyarakat agar dapat mengelola keuangan secara pintar, agar rendahnya pengetahuan akan indutri keuangan dapat diatasi dan masyarakat tidak akan mudah tertipu pada produk-produk investasi yang 
menawarkan keuntungan tinggi dalam jangka pendek tanpa mempertimbangkan resikonya. Untuk memastikan pemahaman masyarakat tentang produk dan layanan yang ditawarkan oleh lembaga jasa keuangan, program strategi nasional literasi keuangan mencanangkan tiga pilar utama. Pertama, mengedepankan program edukasi dan kampanye nasional literasi keuangan. Kedua, berbentuk penguatan infrastuktur literasi keuangan. Ketiga, berbicara tentang pengembangan produk dan layanan jasa keuangan yang terjangkau. Penerapan ketiga pilar tersebut diharapkan dapat mewujudkan masyarakat Indonesia yang memiliki tingkat literasi keuangan yang tinggi sehingga masyarkat dapat memilih dan memanfaatkan produk jasa keuangan guna meningkatkan kesejahteraan. Sedangkan menurut pendapat ahli (Kaly, Hudson dan Vush 2008) dalam penelitian Widyawati (2012) mengartikan bahwa literasi keuangan sebagai kemampuan untuk memahami kondisi keuangan serta konsep- konsep keuangan dan untuk merubah pengetahuan itu secara tepat ke dalamperilaku.

\section{Dasar Literasi Keuangan}

Yang menjadi dasar adanya program literasi keuangan adalah adanya temuan dari bank dunia (2014) bahwa tingkat akses masyarakat Indonesia ke lembaga keuangan, hanya sebesar $36.1 \%$ atau lebih rendah dibanding dengan negara ASEAN lainnya seperti Thailand, Malaysia dan Singapura. Selain itu pula yang menjadi alasan pentingnya literasi keuangan adalah angka rasio savings to GDP Indonesia yaitu sekitar $31 \%$, lebih rendah dari Singapura sebesar 49\%, Filipina sebesar 46\%, serta Cina 49\%. Hal ini dipengaruhi juga tingkat literasi masyarakat Indonesia yang mana pengertian dari literasi keuangan sendiri adalah setiap orang memiliki pengetahuan yang memadai untuk merencanakan dan mengatur keuangan pribadinya dengan tujuan untuk mencapai kesejahteraan. Tingkat literasi yang memadai dapat meningkatakan kehidupan yang lebih baik, terhindar dari kesulitan keuangan.Kesulitan keuangan tidak hanya dikarenakan rendahnya pendapatan seseorang, kesulitan keuangan yang dialami oleh seseorang bukan dari pendapatan semata, tetapi bisa juga disebabkan karena kesalahan management.

\section{Faktor - Faktor Yang Mempengaruhi Tingkat Literasi Keuangan}

Berdasarkan survey Nasional Literasi keuangan dan Inklusi Keuangan factor yang dapat mempengaruhi tingkat literasi keuangan adalah sebagai berikut :

1. Tingkat Pendidikan

Semakin tinggi tingkat pendidikan sesorang maka semakin tinggi pula tingkat literasi keuangan orang tersebut.

2. Strata Sosial

Semakin tinggi kelas strata sosial masyarakat maka akan semakin tinggi pula tingkat literasinya. Kelompok starta sosisal di kelompokkan atas dasar pengeluaran perbulan perkapita.

3. Kelompok Usia

Semakin dewasa usia kelompok masyarakat maka akan semakin tinggi pula tingkat literasinya yang di pengaruhi oleh tingkat pola pikir masyarakat tersebut.

\section{Sikap Terhadap Keuangan \\ Pengertian Sikap Terhadap Uang}

Shohib (2015) mendefinisikan bahwa sikap terhadap uang merupakan sudut pandang atau perilaku seorang individu terhadap uang. Menurut Durvasual dan Lysonski, 2007 menyatakan sikap terhadap uang menunjukan bahwa uang memiliki banyak arti sesuai dengan tingkat pemahaman dan kepribadian seseorang diantaranya uang menjadi bagian penting dalam kehidupannya, sumber rasa hormat, kualitas hidup, kebebasan dan bahkan kejahatan. Yamauchi dan Templer dalam Zahriyan (2106), dalam penelitiannya menjelaskan bahwa terdapat lima dimensi sikap terhadap uang yaitu : 
1. Power-prestige, yang di artikan uang sebagai sumber kekuasaan, pencarian status, alat untuk memperoleh pengakuan dari individu lain, persaingan, dan kepemilikan barangmewah.

2. Retention time, dimana uang adalah faktor penting dalam kehidupan yangharus di kelola dengan baik untuk kepentingan masa depan melalui perencanaan yang matang dan berhati-hati saatmembelanjakannya.

3. Distrut, uang bisa menjadi sumber kecurigaan dan menimbulkan keraguan serta ketidakpercayaan dalam pengambilan keputusan saatpenggunaannya.

4. Quality, dimana uang merupakan sebuah simbol kesuksesan atau simbol kualitas yang mencerminkan prestasiseseorang.

5. Anxiety, dimana uang di gambarkan sebagai peneybab kegelisahan yang bisa menimbulkan stress bagipemiliknya.

Sikap individu, sikap individu terhadap uang dipegaruhi oleh banyak faktor diantaranya pengalaman masa kanak-kanak individu, pendidikan, keuangan, status sosial ekonomi dan keluarga (Taneja, 2012). Memahami sikap orang terhadap uang menjadi penting karena dapat menentukan perilaku uang seorang individu. Perilaku sosial yang muncul dari individu dapat dilihat dari bagaimana seseorang memandang uang, perilaku berbelanja atau perilaku ekonomi lainnya ( menabung, berutang, investasi dan kerja) dapat dihubungkan dengan sikap terhadap uang dan kesehatan mental seseorang juga dapat dikaitkan dengan uang.

\section{Pengelolaan Keuangan \\ Pengertian Pengelolaan Keuangan}

Perilaku pengelolaan keuangan merupakan suatu cara dalam mengelola dana yang dimiliki yang berhubungan dengan tanggung jawab seseorang dalam mengelola keuangan. Tanggungjawab keuangan merupakan proses pengelolaan uang dan asset keuangan ( Ida dan Cintia, 2010). Individu yang memiliki tanggungjawab keuangan cenderung mengelola keuangan denga baik. Dengan pengelolaan keuangan yang baik, maka tidak akan terjebak pada prilaku keinginan yang tidak terbatas (Meliza dan Norma, 2013) Perilaku pengelolaan keuangan yang baik diukur dengan lima komponen dari kemampuan seseorang dalam menganggarkan, menghemat uang, dan mengatur pengeluaran (Perry dan Morris, 2015). Lima komponen tersebut terdiri dari mampu membelanjakan uang seperlunya, membayar kewajiban bulanan tepat waktu, merencanakan keuangan tepat waktu, merencanakan keuangan untuk keperluan masa depan, menabung, dan menyisihkan dana untuk diri sendiri. Menurut Warsono 2010 dalam mengelola keuangan pribadi, terdapat empat (4) ranah yang menjadi kajian pokok yaitu penggunaan dana, penentuan sumber dana, manajemen resiko, jiwa dan asset, dan perencanaan pensiun.

\section{METODOLOGI PENELITIAN Sumber Data Penelitian}

Sumber data dalam penelitian ini adalah data primer. Data primer dalam penelitian ini diperoleh melalui kuesioner yang disebarkan kepada masyarakat Kecamatan Sekupang. Teknik pengambilan sampling yang digunakan adalah convenience sampling (Uma : 2003) yaitu suatu teknik pengambilan sample berdasarkan kemudahan sample berdasarkan sampling digunakan karena dianggap lebih mudah dan tidak menghabiskan dari responden, berdasarkan pendapatan atau penghasilan dari keluarga, yakni dari suami / istri yang ada di Kecamatan Sekupang Kota Batam. Serta teknik pengambilan sampel yang digunakan purposive sampling berdasarkan pendapatan atau penghasilan keluarga dengan pendapatan minimal Rp.3.500.000,- dan melibatkan 200 responden. 


\section{P-ISSN: 2598-5035; E-ISSN: 2684-8244}

\section{Operasional Variabel}

Menurut sugiyono (2010) variabel penelitian adalah suatu atribut atau nilai dari orang, obyek atau kegiatan yang mempunyai variasi tertentu yang ditetapkan oleh peneliti untuk dipelajari dan ditarik kesimpulannya.Sedangkan Arfan (2010) variable merupakan suatu sifat yang dapat memiliki berbagai macam nilai. Operasional variabel diperlukan dalam menentukan jenis, indikator, serta skala dari variabel yang terkait suatu penelitian, sehingga pengujian hipotesis dengan alat bantu statistik dapat dilakukan secara benar sesuai dengan judul penelitian yaitu "Pengaruh Literasi Keuangan dan Sikap Terhadap Uang Pada Pengelolaan Keuangan Keluarga Masyarakat Kecamatan Sekupang".

Berdasarkan judul penelitian di atas, maka variabel-variabel yang terkait dalam penelitian ini adalah sebagai berikut:

1. Variabel Independen $(X)$

Variabel independen adalah suatu variabel bebas dimana keberadaanya tidak di pengaruhi oleh variabel ini merupakan faktor penyebab yang akan mempengaruhi variabel lainnya (Sugiyono, 2010). Variabel independen (X1) dalam penelitian ini adalah literasi keuangan dan Variabel independen $(\mathrm{X} 2)$ adalah sikap terhadap uang.

2. Variabel Dependen $(Y)$

Variabel dependen adalah variabel yang tidak bebas yang artinya variabel tersebut merupakan sesuatu yang dipengaruhi atau yang dihasilkan oleh variabel independen. Menurut Sugiyono (2010) Variabel Dependen (terikat) adalah variabel yang dipengaruhi atau yang menjadi akibat, karena adanya variabel bebas. Maka dalam penelitian ini variabel dependen atau variabel tidak bebas (Y) adalah pengelolaan keuangan pribadi masyarakat.

Untuk mempermudah mendapatkan data yang diperlukan bagi penelitian dari masalah yang diteliti, perlu adanya operasional variabel. Opearsional variabel yaitu memecah variabel-variabel yang ada atau terkandung dalam masalah tersebut diatas menjadi bagian-bagian yang paling kecil, sehingga dapat diketahui klasifikasi ukurannya.

Tabel 1 Definisi Operasional Variabel

\begin{tabular}{|c|c|c|}
\hline Variable & Indikator & Keterangan \\
\hline $\begin{array}{l}\text { (X1) } \\
\text { Literasi } \\
\text { Keuangan } \\
\text { Iklima Humaira, } \\
2017\end{array}$ & $\begin{array}{l}\text { 1. Pengetahuan } \\
\text { pengelolaan } \\
\text { keuangan } \\
\text { 2. Pengetahuan } \\
\text { tentang } \\
\text { perencanaan } \\
\text { keuangan } \\
\text { 3. Pengetahuann } \\
\text { tentang } \\
\text { pengeluaran dan } \\
\text { pemasukan } \\
\text { 4. Pengetahuan dasar } \\
\text { tentang investasi. } \\
\text { 5. Pengetahuan } \\
\text { keuangan dalam } \\
\text { keadaan sehat }\end{array}$ & 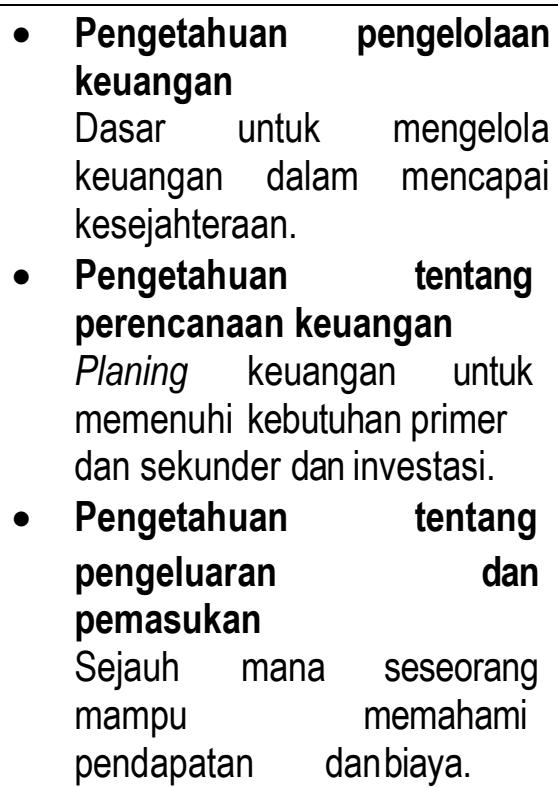 \\
\hline
\end{tabular}

Hal. 37 


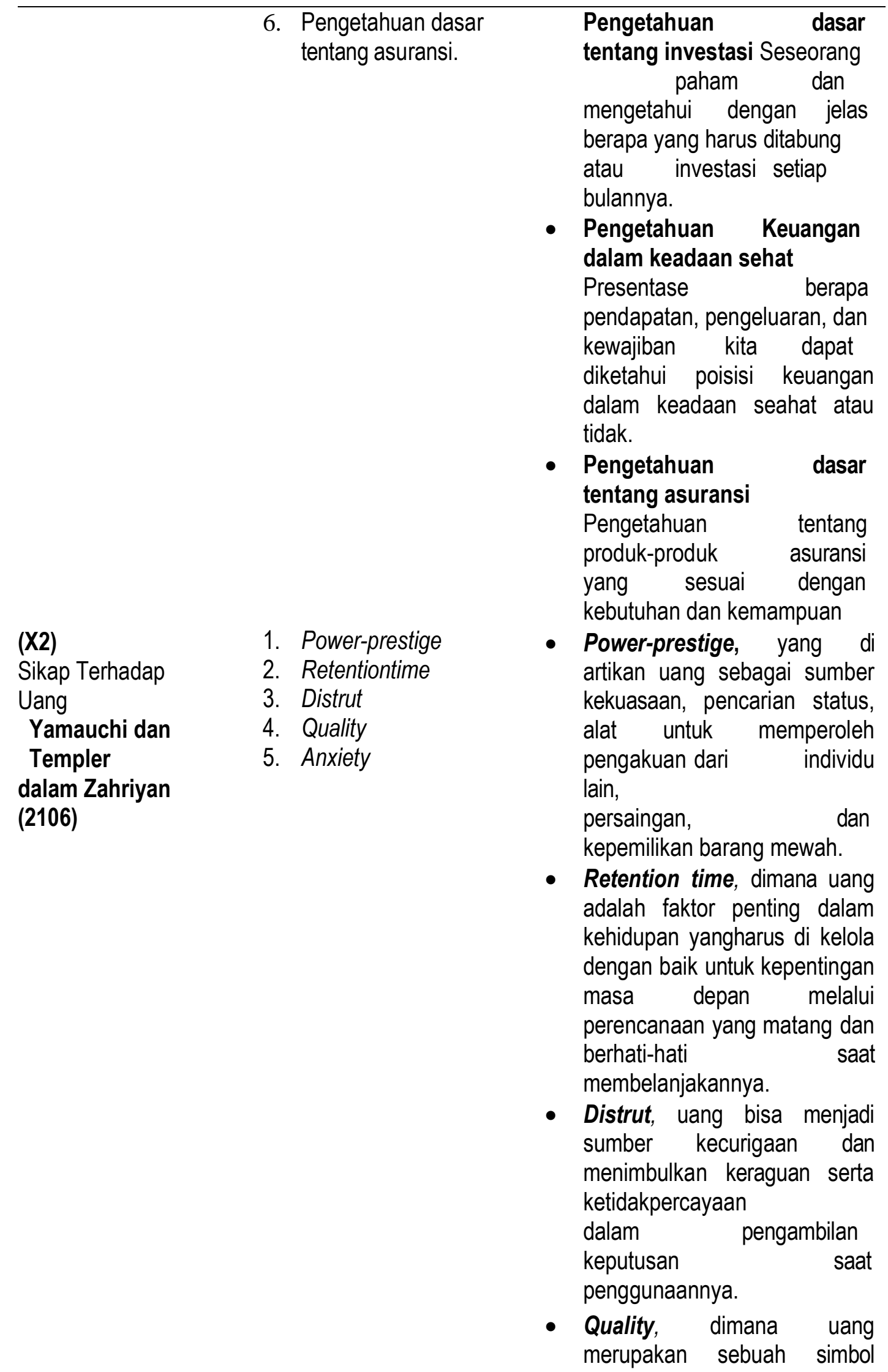




\section{(Y) \\ Pengelolaan keuangan \\ Iklima \\ Humaira,2017}

1. Jenis-Jenis perencanaan keuangan dan anggaran yang dimiliki.

2. Teknik dalam menyusun perencanaan keuangan

3. Kegiatan menabung.

4. Pembayaran tagihan tepat waktu

5. Monitoring pengelolaan keuangan.

6. Evaluasi Pengelolaan Keuangan. $\begin{array}{lcc}\begin{array}{l}\text { kesuksesan } \\ \text { kualitas }\end{array} & \text { atau } & \begin{array}{c}\text { simbol } \\ \text { yang }\end{array} \\ \text { mencerminkan } & & \text { prestasi }\end{array}$ seseorang.

- Anxiety, dimana uang di gambarkan sebagai peneybab kegelisahan yang bisa menimbulkan stress bagi pemiliknya.

- Financial planning Perencanaan keuangan penting dilakukan agaruang yang dimiliki sesuai peruntukannya untuk memenuhi kebutuhan hidup. Dari perencanaan keuangan juga dapat mengetahui bagaiman kita harus mengatur pengeluaran sesuai income yang kita terima setiap bulannya.

- Teknik dalam menyusun perencanaan keuangan Strategi dalam menyusun perencanaan keuangan sesuai dengan kebutuhan masing-masing pribadi.

- Kegiatan menabung

Pendapatan yang kita terima setiap bulannya, sangat buruk jika dihabiskan semua tanpa disisihkan untuk tabungan ataupun investasi. Pentingnya menabungdan investasi untuk persiapan dana dimasa depan.

- Pembayaran Tagihan Tepat Waktu

Suatu tagihan yang sudah menjadi seseorang kewajiban menghindari denda pembayaran dan juga menghindari suasana yang kurang kondusif seseorang 
harus sudah merencanakan jauh-jauh hari sehingga tagihan tersebut terbayar sebelum jatuh tempo.

- Monitoring keuangan

Perencanaan keuagan yang sudah dibuat perlu di monitoring bagaimana dalam pelaksanaanya.

- Evaluasi Keuangan

Pengelolaan

Keuangan yang sudah direncanakan dan dilakukan tidak lepas dari kekurangan dari rencana yang sudah ditetapkan diawal , atau untuk mencapai hasil yang lebih maksimal perlu dilakukan evaluasi

- pengelolaan keuangan seacar rutin.

\section{HASIL PENELITIAN}

Karakteristik Responden

Tabel 2. Jenis_Kelamin

\begin{tabular}{llrrrr}
\hline & & Frequency & Percent & Valid Percent & $\begin{array}{c}\text { Cumulative } \\
\text { Percent }\end{array}$ \\
\hline Valid & Laki-laki & 132 & 66.0 & 66.0 & 66.0 \\
& Perempuan & 68 & 34.0 & 34.0 & 100.0 \\
& Total & 200 & 100.0 & 100.0 & \\
\hline
\end{tabular}

Berdasarkan tabel di atas dapat dilihat bahwa sebanyak $132(66 \%)$ responden laki-laki dan sisanya sebanyak 68 orang $(34 \%)$ adalah responden perempuan.Dengan demikian responden penelitian dengan sebanyak 132 responden (66\%) didominasi oleh responden yang berjenis kelamin laki-laki.

Tabel 3. Usia_Responden

\begin{tabular}{llrrrr}
\hline & & & & \multicolumn{2}{c}{ Cumulative } \\
\hline Valid & 15 - 25 Tahun & 27 & 13.5 & 13.5 & 13.5 \\
& 25 - 35 Tahun & 88 & 44.0 & 44.0 & 57.5 \\
& 35 - 45 Tahun & 72 & 36.0 & 36.0 & 93.5 \\
& > 45 Tahun & 13 & 6.5 & 6.5 & 100.0 \\
Total & 200 & 100.0 & 100.0 & \\
\hline
\end{tabular}


Berdasarkan tabel di atas, jumlah responden berdasarkan usia dalam penelitian ini responden berusia 15 25 tahun sebanyak 27 orang (13.5\%), usia 25 - 35 tahun sebanyak 88 orang (44\%), 35 - 45 tahun sebanyak 72 orang $(36 \%)$ dan usia $>45$ tahun sebanyak 13 orang $(6.5 \%)$. Dengan demikian responden dengan kriteria usia didominasi oleh usia 25 - 35 tahun sebanyak 88 orang (44\%).

Tabel 4. Pekerjaan

\begin{tabular}{llrrrr}
\hline & & & \multicolumn{2}{c}{ Cumulative } \\
Valid & Wrequency & Percent & Valid Percent & Percent \\
\cline { 2 - 5 } & Karyawana Swasta & 150 & 15.0 & 15.0 & 15.0 \\
& PNS & 75.0 & 75.0 & 90.0 \\
& Lain-lain & 2.5 & 2.5 & 92.5 \\
& Total & 15 & 7.5 & 7.5 & 100.0 \\
\hline
\end{tabular}

Berdasarkan tabel di atas, dapat dilihat bahwa jumlah responden yang bekerja sebagai wirausaha sebanyak $30(15 \%)$ orang, karyawan swasta sebanyak $150(75 \%)$ orang, PNS sebanyak $5(2.5 \%)$ orang, dan Lain-lain yang terdiri dari tidak bekerja, dosen, mahasiswa, dan pekerjaan lainnya sebanyak 15 (7.5\%) orang. Dengan demikian, responden yang berkerja sebagai karyawan swasta mendominasi sebanyak 150 $(75 \%)$ orang.

Tabel 5. Pendapatan

\begin{tabular}{llrrrr}
\hline & & Percen & \multicolumn{2}{c}{$\begin{array}{c}\text { Valid } \\
\text { Cumulative }\end{array}$} \\
\hline Valid & Rp 1.500.000 - Rp 2.500.000 & Frequency & \multicolumn{1}{c}{ C } & Percent & Percent \\
& Rp 2.500.00 - Rp 3.500.000 & 11 & 5.5 & 5.5 & 5.5 \\
Rp 3.500.000 - Rp 4.500.000 & 25 & 12.5 & 12.5 & 18.0 \\
Rp 4.500.000 - Rp 5.500.000 & 57 & 28.5 & 28.5 & 46.5 \\
>Rp 5.500.000 & 72 & 36.0 & 36.0 & 82.5 \\
Total & 35 & 17.5 & 17.5 & 100.0 \\
\hline
\end{tabular}

Berdasarkan tabel di atas, dapat dilihat responden yang memiliki pedapatan Rp 1.500.000 - Rp 2.500.000 sebanyak 11 (12.5\%) orang, Rp 2.500.000 - Rp 3.500.000 sebanyak 25 (12.5\%) orang, Rp 3.500.000 - Rp 4.500 .000 sebanyak 57 (28.5\%) orang, Rp 4.500 .000 - Rp 5.500 .000 sebanyak 72 (36\%) orang, dan pendapatan > Rp 5.500 .000 sebanyak $35(17.5 \%)$ orang. Dengan demikian, responden yang memiliki pendapatan Rp 4.500.000 - Rp 5.500.000 mendominasi jumlah responden sebanyak 72 orang (36\%) dari 200 responden yang diteliti.

\section{Alat Uji Kusioner}

Uji validitas digunakan untuk mengukur ketetapan suatu item dalam kuesioner atau skala yang ingin diukur. Dalam penentuan valid atau tidaknya item yang digunakan, kegiatan yang harus dilakukan adalah dengan membandingkan rhitung dengan rtabel dimana taraf signifikansi yang digunakan adalah 0,05 dengan $\mathrm{N}=$ 200. Untuk mengetahui tingkat validitas tersebut, maka akan dilakukan terlebih dahulu uji statistik dengan menggunakan program SPSS 20, berikut hasil output untuk masing-masing variabel.

1) Uji Variabel Literasi Keuangan

Berikut ini hasil output statistik untuk validitas item-item pernyataan pada variabel literasi keuangan yang dapat dilihat pada tabel berikut dengan $\mathrm{df}=\mathrm{N}-2$. 
Tabel 6. Uji Variabel Literasi Keuangan

\begin{tabular}{cccc}
\hline $\begin{array}{c}\text { Item } \\
\text { Pernyataan }\end{array}$ & $\mathbf{r}_{\text {hitung }}$ & $\mathbf{r}_{\text {tabel }}$ & Kesimpulan \\
\hline Item 1 & 0.6420 & 0.1388 & Valid \\
Item 2 & 0.6760 & 0.1388 & Valid \\
Item 3 & 0.7540 & 0.1388 & Valid \\
Item 4 & 0.7690 & 0.1388 & Valid \\
Item 5 & 0.6600 & 0.1388 & Valid \\
Item 6 & 0.5930 & 0.1388 & Valid \\
Item 7 & 0.6640 & 0.1388 & Valid \\
Item 8 & 0.7100 & 0.1388 & Valid \\
Item 9 & 0.4180 & 0.1388 & Valid \\
Item 10 & 0.3960 & 0.1388 & Valid \\
Item 11 & 0.5190 & 0.1388 & Valid \\
\hline
\end{tabular}

Dapat dilihat bahwa berdasarkan tabel di atas, secara keseluruhan item pertanyaan pada variabel literasi keuangan $\left(X_{1}\right)$ dapat dinyatakan valid karena seluruh item pernyataan memiliki nilai $\boldsymbol{r}_{\text {hitung }}$ yang lebih besar dari hasil $\boldsymbol{r}_{\text {tabel }}$ sebesar 0.1388 .

2) Uji Variabel Sikap Terhadap Uang

Berikut ini hasil output statistik untuk validitas item-item pernyataan pada variabel sikap terhadap uang yang dapat dilihat pada tabel berikut dengan $\mathrm{df}=\mathrm{N}-2$.

Tabel 7. Uji Variabel Sikap Terhadap Keuangan

\begin{tabular}{cccc}
\hline $\begin{array}{c}\text { Item } \\
\text { Pernyataan }\end{array}$ & rhitung & rtabel & Kesimpulan \\
\hline Item 1 & 0.6410 & 0.1388 & Valid \\
Item 2 & 0.6830 & 0.1388 & Valid \\
Item 3 & 0.4530 & 0.1388 & Valid \\
Item 4 & 0.5220 & 0.1388 & Valid \\
Item 5 & 0.5630 & 0.1388 & Valid \\
Item 6 & 0.6570 & 0.1388 & Valid \\
Item 7 & 0.4490 & 0.1388 & Valid \\
Item 8 & 0.3490 & 0.1388 & Valid \\
Item 9 & 0.1820 & 0.1388 & Valid \\
\hline
\end{tabular}

Dapat dilihat bahwa berdasarkan tabel di atas, secara keseluruhan item pertanyaan pada variabel sikap terhadap uang $\left(X_{2}\right)$ dapat dinyatakan valid karena seluruh item pernyataan memiliki nilai $\boldsymbol{r}_{\text {hitung }}$ yang lebih besar dari hasil $\boldsymbol{r}_{\text {tabel }}$ sebesar 0.1388 .

3) Uji Variabel Pengelolaan Keuangan

Berikut ini hasil output statistik untuk validitas item-item pernyataan pada variabel pengelolaan keuangan yang dapat dilihat pada tabel berikut dengan $\mathrm{df}=\mathrm{N}-2$.

Tabel 8. Uji Variabel Pengelolaan Keuangan

\begin{tabular}{cccc}
\hline $\begin{array}{c}\text { Item } \\
\text { Pernyataan }\end{array}$ & $\boldsymbol{r}_{\text {hitung }}$ & $\boldsymbol{r}_{\text {tabel }}$ & Kesimpulan \\
\hline Item 1 & 0.6880 & 0.1388 & Valid \\
Item 2 & 0.6270 & 0.1388 & Valid \\
Item 3 & 0.6670 & 0.1388 & Valid \\
Item 4 & 0.6020 & 0.1388 & Valid
\end{tabular}




$\begin{array}{cccc}\text { Item } 5 & 0.5190 & 0.1388 & \text { Valid } \\ \text { Item 6 } & 0.5140 & 0.1388 & \text { Valid } \\ \text { Item 7 } & 0.4450 & 0.1388 & \text { Valid } \\ \text { Item 8 } & 0.4540 & 0.1388 & \text { Valid } \\ \text { Item 9 } & 0.4060 & 0.1388 & \text { Valid } \\ \text { Item 10 } & 0.6660 & 0.1388 & \text { Valid }\end{array}$

Dapat dilihat bahwa berdasarkan tabel di atas, secara keseluruhan item pertanyaan pada variabel pengelolaan keuangan $(Y)$ dapat dinyatakan valid karena seluruh item pernyataan

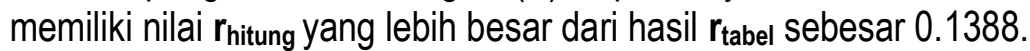

4) Uji Reliabilitas

Uji reabilitas dilakukan untuk mengetahui konsistensi alat ukur, apakah alat ukur yang digunakan dapat diandalkan dan tetap konsisten jika pengukurannya diulang. Dalam hal ini uji reliabilitas dilakukan dengan menggunakan metode Cronbach's Alpha, dengan kriteria bahwa tingkat alpha hitung lebih besar dari koefisien Alpha Cronbach sebesar 0,70 maka data yang diujikan memiliki tingkat reliabilitas yang baik.Jika nilai alpha $>0.7$ artinya reliabilitas mencukupi (sufficient reliability) sementara jika alpha $>0.80$ ini mensugestikan seluruh item reliabel dan seluruh tes secara konsisten memiliki reliabilitas yang kuat.

\section{Tabel 9. Uji Rehabilitas}

\begin{tabular}{cccc}
\hline No. & \multicolumn{1}{c}{ Variabel } & $\begin{array}{c}\text { Nilai Cronbach's } \\
\text { Alpha }\end{array}$ & Kesimpulan \\
\hline 1. & Literasi Keuangan $\left(\mathrm{X}_{1}\right)$ & 0.890 & Reliabel \\
2. & Sikap Terhadap Uang $\left(\mathrm{X}_{2}\right)$ & 0.808 & Reliabel \\
3. & Pengelolaan Keuangan $(\mathrm{Y})$ & 0.851 & Reliabel \\
\hline
\end{tabular}

Berdasarkan tabel di atas dapat dilihat bahwa hasil uji reliabilitas variabel $\mathrm{X}_{1}$ menunjukkan hasil Cronbach's Alpha sebesar 0.890 yang mana lebih besar dari nilai koefisien Alpha Cronbach's 0.70 maka dapat disimpulkan bahwa alat ukur dalam penelitian ini adalah reliable. Cronbach's Alpha untuk variabel $X_{2}$ diperoleh hasil statistiknya sebesar 0,808 yang mana juga lebih besar dibandingkan nilai koefisien Alpha Cronbach's 0.70 maka dapat disimpulkan bahwa alat ukur dalam penelitian ini adalah reliable. Sedangkan untuk pengujian Cronbach's Alpha pengelolaan keuangan $(Y)$ sebesar 0.851 yang mana lebih besar dari nilai koefisien Alpha Cronbach's 0.70 maka dapat disimpulkan bahwa alat ukur dalam penelitian ini adalah reliable.

a. Hasil Uji Asumsi Klasik

1) Uji normalitas

Hasil output uji normalitas data dari tabel diatas dapat diketahui bahwa nilai signifikansi (Asymp. Sig-2tailed) sebesar pada masing-masing variable adalah: Literasi Keuangan 0,234, Sikap Terhadap Uang 0,234, dan Pengelolaan Keuangan 0,087. Karena signifikansi lebih dari 0,05 , maka residual berdistribusi dengan normal. 
2) Uji Multikolonearitas

Pengujian multikolinieritas bertujuan untuk mengetahui hubungan sempurna antara variabel bebas dalam model regresi. Gejala multikolinieritas dapat dilihat dari nilai tolerance dan nilai varian inflation factor (VIF). Bila nilai VIF lebih kecil dari 10 dan nilai toleransinya diatas 0,1 atau $10 \%$ maka dapat disimpulkan bahwa model regresi tersebut tidak terjadi multikolinieritas, Wibowo (2012) dalam Hamta (2015). Hasil uji multikolinieritas dapat dilihat pada tabel berikut ini.

\begin{tabular}{cccc}
\hline \hline Variabel & Tolerance & VIF & Keterangan \\
\hline $\mathrm{X}_{1}$ & 0.979 & 1.021 & Tidak Terjadi Multikolinearitas \\
$\mathrm{X}_{2}$ & 0.979 & 1.021 & Tidak Terjadi Multikolinearitas \\
& & Tabel 11. Uji Multikolonearitas
\end{tabular}

Berdasarkan tabel di atas menunjukan bahwa nilai tolerance dan VIF dari variabel literasi keuangan adalah sebesar 0,979>0,1 dan VIF sebesar 1,021. Kemudian variabel sikap terhadap uang memiliki nilai tolerance dan VIF adalah sebesar 0,979 $>0,1$ dan VIF sebesar 1,021. Sehingga dapat dinyatakan dalam model penelitian ini tidak terdapat masalah multikolinieritas antara variabel bebas karena nilai tolerance bearada dibawah 1 dan nilai VIF jauh dibawah angka 10.

3) Uji Heteroskedastisitas

Pengujian heteroskedasitas bertujuan untuk menguji apakah dalam model regresi terjadi ketidaksamaan variance dari residual satu pengamatan ke pengamatan lain. Pada model regresi yang baik adalah yang tidak terjadi heteroskedasitas.Cara untuk mendeteksi adanya heteroskedasitas pada suatu model dapat dilihat dari pola Scatteroplot model tersebut.Jika output Scatteroplot menunjukan penyebaran butir-butir data yang berpola jelas, maka dapat diidentifikasi telah terjadi heteroskedasitas.

4) Uji Autokeralasi

Autokorelasi bertujuan untuk menguji apakah dalam sebuah model regresi linear terdapat korelasi antara kesalahan pengganggu pada periode ke t dengan kesalahan pada periode $\mathrm{t}-1$ (sebelumnya).Jika terjadi korelasi, maka dinamakan ada problem autokorelasi.Model regresi yang baik adalah bebas dari autokorelasi.

Salah satu cara mengidentifikasikannya adalah dengan melihat nilai Durbin Watson (D-W): (1) jika nilai D-W di bawah -2 berarti terdapat autokorelasi positif; (2) jika nilai D-W diantara -2 sampai +2 berarti tidak terdapat autokorelasi; (3) jika nilai $D-W$ di atas +2 berarti terdapat autokorelasi negatif.

Tabel 12. Uji Autokeralasi Model Summary

\begin{tabular}{lrrrrr}
\hline Model & $\mathrm{R}$ & $\mathrm{R}$ Square & $\begin{array}{c}\text { Adjusted } \mathrm{R} \\
\text { Square }\end{array}$ & $\begin{array}{c}\text { Std. Error of } \\
\text { the Estimate }\end{array}$ & Durbin-Watson \\
\hline 1 & $.677^{\mathrm{a}}$ & .458 & .452 & 4.58086 & 1.897 \\
\hline
\end{tabular}

a. Predictors: (Constant), Sikap Terhadap Uang, Literasi Keuangan

b. Dependent Variable: Pengelolaan Keuangan 


\section{P-ISSN: 2598-5035; E-ISSN: 2684-8244}

Berdasarkan hasil pengujian autokorelasi dengan bantuan program komputer SPSS 20.00 diperoleh nilai Durbin-Watson (DW) 1.897.Dengan nilai DW 1.897yang berada di antara -2 sampai +2 maka dapat disimpulkan bahwa model regresi dalam penelitian ini tidak ada masalah autokorelasi.

Berdasarkan uji asumsi klasik (normalitas, autokorelasi, multikolinearitas, heteroskedastisitas) diperoleh bahwa dalam model yang digunakan sudah terjadi penyimpangan asumsi klasik, artinya model regresi pada penelitian dapat digunakan sebagai dasar analisis.

b. Analisis Regresi Linear Berganda

Analisis data dalam penelitian ini dimaksudkan untuk mengetahui ada tidaknya pengaruhLiterasi Keuangan $\left(X_{1}\right)$ danSikap Terhadap Uang $\left(X_{2}\right)$ terhadap Pengelolaan Keuangan (Y).Analisis ini dilakukan dengan menggunakan analisis regresi linear berganda.Hasil analisis regresi berganda dapat dilihat pada tabel dibawah ini.

\section{Tabel 13. Analisa Regresi Linear Berganda} Coefficients ${ }^{a}$

\begin{tabular}{|c|c|c|c|c|c|c|c|c|}
\hline \multirow[b]{2}{*}{ Mode } & & \multicolumn{2}{|c|}{$\begin{array}{l}\text { Unstandardized } \\
\text { Coefficients }\end{array}$} & \multicolumn{2}{|l|}{$\begin{array}{l}\text { Standardized } \\
\text { Coefficients }\end{array}$} & \multicolumn{3}{|c|}{$\begin{array}{l}\text { Collinearity } \\
\text { Statistics } \\
\text { Toleranc }\end{array}$} \\
\hline & & B & Std. Error & Beta & $\mathrm{t}$ & Sig. & e & VIF \\
\hline \multirow[t]{3}{*}{1} & (Constant) & 7.799 & 2.336 & & 3.339 & .001 & & \\
\hline & Literasi Keuangan & .536 & .047 & .606 & 11.424 & .000 & .979 & 1.021 \\
\hline & $\begin{array}{l}\text { Sikap Terhadap } \\
\text { Uang }\end{array}$ & .227 & .053 & .227 & 4.274 & .000 & .979 & 1.021 \\
\hline
\end{tabular}

a. Dependent Variable: Pengelolaan Keuangan

Dari tabel tersebut dapat disusun persamaan regresi linear berganda sebagai berikut:

\section{$Y=7.799+0,536 X_{1}+0.227 X_{2}$}

Berdasarkan persamaan regresi linier berganda di atas dapat diuraikan sebagai berikut:

a. Nilai konstanta bernilai positif yaitu 7.799 hal ini menunjukkan bahwa apabila variabel Literasi Keuangan $\left(\mathrm{X}_{1}\right)$ danSikap Terhadap Uang $\left(\mathrm{X}_{2}\right)$ konstan, maka Pengelolaan Keuangan $(\mathrm{Y})$ akan naik sebesar 7.799 .

b. Koefisien regresi variabel sistem Literasi Keuangan (b1) bernilai positif yaitu sebesar 0.536 . Hal ini menunjukkan apabila Literasi Keuangan $\left(\mathrm{X}_{1}\right)$ meningkat, maka Pengelolaan Keuangan ( $\mathrm{Y}$ ) akan naik sebesar 0.536 dengan anggapan variabel bebas lainnya konstan.

c. Koefisien regresi variabel Sikap Terhadap Uang(b2) bernilai positif yaitu sebesar 0.277 . Hal ini menunjukkan apabilaSikap Terhadap Uang $\left(\mathrm{X}_{2}\right)$ meningkat, maka Pengelolaan Keuangan ( $\mathrm{Y}$ ) akan naik sebesar 0.277 dengan anggapan variabel bebas lainnya konstan.

c. Pengujian Model

1) Uji Koefisien Determinasi

Pengujian ini dipergunakan untuk menghitung seberapa besar varian variabel dependen yang dapat dijelaskan oleh variabel-variabel independen. $\mathrm{R}^{2}$ yang digunakan adalah $\mathrm{R}^{2}$ yang telah mempertimbangkan jumlah variabel independen dalam suatu model regresi atau disebut $\mathrm{R}^{2}$ yang telah disesuaikan (Adjusted- $\mathrm{R}^{2}$ ). 
Dalam penelitian ini digunakan Adjusted- $R^{2}$ karena jika jumlah variabel independen yang diteliti lebih dari dua variabel.

\section{Tabel 14. Uji Koefisien Determinasi}

Model Summaryb

\begin{tabular}{lrrrrr}
\hline Model & $\mathrm{R}$ & R Square & $\begin{array}{c}\text { Adjusted R } \\
\text { Square }\end{array}$ & $\begin{array}{r}\text { Std. Error of } \\
\text { the Estimate }\end{array}$ & Durbin-Watson \\
\hline 1 & $.677^{\mathrm{a}}$ & .458 & .452 & 4.58086 & 1.897 \\
\hline
\end{tabular}

a. Predictors: (Constant), Sikap Terhadap Uang, Literasi Keuangan

b. Dependent Variable: Pengelolaan Keuangan

Berdasarkan tabel di atas tersebut dapat dilihat hasil Adjusted- $\mathrm{R}^{2}$ dengan bantuan program SPSS dalam analisis regresi berganda diperoleh angka determinasi yang disesuaikan atau Adjusted- $\mathrm{R}^{2}$ sebesar 0.452 . Hal ini berarti 45\% variasi Adjusted R Square dijelaskan oleh variasi perubahan faktor-faktor literasi keuangan $\left(X_{1}\right)$ dansikap terhadap uang $\left(X_{2}\right)$ secara bersama-sama (simultan) terhadap pengelolaan keuangan $(Y)$. Sementara sisanya sebesar $55 \%$ dipengaruhi oleh faktor-faktor lain yang tidak ikut terobservasi yang mempengaruhi variabel pengelolaan keuangan.Oleh sebab itu, diperlukan pengembangan penelitian lebih lanjut.

2) Uji Model Fit (Uji F)

Uji F digunakan untuk mengetahui pengaruh variabel bebas (independen) yaitu Literasi Keuangan $\left(X_{1}\right)$ danSikap Terhadap Uang $\left(X_{2}\right)$ terhadap Pengelolaan Keuangan $(Y)$ dengan

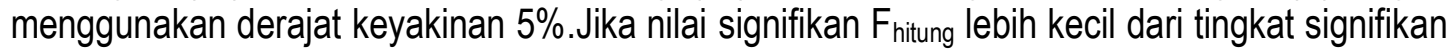
tertentu (5\%) maka yang diuji adalah signifikan dalam menentukan variabilitas variabel.

Tabel 15. Uji Model Fit ( Uji F) ANOVA $^{a}$

\begin{tabular}{|c|c|c|c|c|c|c|}
\hline Model & & $\begin{array}{l}\text { Sum of } \\
\text { Squares }\end{array}$ & $d f$ & Mean Square & $\mathrm{F}$ & Sig. \\
\hline \multirow[t]{3}{*}{1} & Regression & 3491.108 & 2 & 1745.554 & 83.184 & $.000^{b}$ \\
\hline & Residual & 4133.912 & 197 & 20.984 & & \\
\hline & Total & 7625.020 & 199 & & & \\
\hline
\end{tabular}

a. Dependent Variable: Pengelolaan Keuangan

b. Predictors: (Constant), Sikap Terhadap Uang, Literasi Keuangan

Berdasarkan table di atas diperoleh hasil analisis untuk nilai $F$ adalah sebesar 83.184 dengan probabilitas sebesar 0.000 . Nilai $F$ tabel $\left.\right|_{0.05(2)(200)}$ adalah sebesar 3.04 . Oleh karena itu dengan nilai $F$ hitung lebih besar dari $F$ tabel $0_{0.05(2)(200)}$ yaitu $459.794>3.04$ atau probabilitas $F$ hitung 0.000 lebih kecil dari 0.05 maka $\mathrm{H} 0$ ditolak dan $\mathrm{H} 1$ diterima. Hal tersebut membuktikan bahwa terdapat pengaruh yang signifikan antara Literasi Keuangan $\left(X_{1}\right)$ danSikap Terhadap Uang $\left(\mathrm{X}_{2}\right)$ terhadap Pengelolaan Keuangan $(\mathrm{Y})$.

d. Uji Hipotesis (Uji-t)

Uji t digunakan untuk mengetahui besarnya pengaruh masing-masing variabel independen secara individu. Pengujian regresi yang digunakan ada pengujian dua arah (two tailed test) dengan 
P-ISSN: 2598-5035; E-ISSN: 2684-8244

menggunakan $a=5 \%$ yang berarti bahwa tingkat keyakinan adalah sebesar $95 \%$. Hasil uji t dapat dilihaat pada tabel berikut ini.

Tbel 16. Uji Hipotesis ( Uji - t)

Coefficients ${ }^{a}$

\begin{tabular}{|c|c|c|c|c|c|c|c|c|}
\hline \multirow[b]{2}{*}{ Model } & & \multicolumn{2}{|c|}{$\begin{array}{l}\text { Unstandardized } \\
\text { Coefficients }\end{array}$} & \multicolumn{2}{|l|}{$\begin{array}{l}\text { Standardized } \\
\text { Coefficients }\end{array}$} & \multicolumn{3}{|c|}{$\begin{array}{l}\text { Collinearity } \\
\text { Statistics } \\
\text { Toleranc }\end{array}$} \\
\hline & & B & Std. Error & Beta & $t$ & Sig. & $\mathrm{e}$ & VIF \\
\hline \multirow[t]{3}{*}{1} & (Constant) & 7.799 & 2.336 & & 3.339 & .001 & & \\
\hline & Literasi Keuangan & .536 & .047 & .606 & 11.424 & .000 & .979 & 1.021 \\
\hline & $\begin{array}{l}\text { Sikap Terhadap } \\
\text { Uang }\end{array}$ & .227 & .053 & 227 & 4.274 & .000 & .979 & 1.021 \\
\hline
\end{tabular}

a. Dependent Variable: Pengelolaan Keuangan

1. Literasi Keuangan $\left(X_{1}\right)$

Berdasarkan tabel di atas hasil pengolahan variabel Literasi Keuangan $\left(X_{1}\right)$ diperoleh nilai t hitung sebesar 11.424 dengan probabilitas 0.000 . Dengan $t$ hitung 11.424lebih besar dari $t-$ tabel $0_{0.05(200)} 1.97190$ atau probabilitas 0.000 lebih kecil dari 0.05 ; maka $\mathrm{H}_{0}$ ditolak yang berarti bahwa variabel Literasi Keuangan $\left(X_{1}\right)$ secara parsial atau individu berpengaruh signifikan secara positif terhadap Pengelolaan Keuangan.

2. Sikap Terhadap Uang $\left(\mathrm{X}_{2}\right)$

Berdasarkan tabel di atas hasil pengolahan variabel Sikap Terhadap Uang $\left(\mathrm{X}_{2}\right)$ diperoleh nilai $t$ hitung sebesar 4.274 dengan probabilitas 0.000 . Dengan $t$ hitung 4.274lebih kecil dari ttabel $_{0.05(200)} 1.97190$ atau probabilitas 0.000 lebih besar dari 0.05 ; maka $\mathrm{H}_{0}$ diterima yang berarti bahwa variabel Sikap Terhadap Uang $\left(\mathrm{X}_{2}\right)$ secara parsial atau individu tidak berpengaruh terhadap Pengelolaan Keuangan.

\section{REKOMENDASI}

Berdasarkan hasil pengujian data yang diproses SPSS V.20, sesuai dengan penelitian ini, maka rekomendasi hasil penelitian ini antara lain :

1. Literasi keuangan secara parsial atau individu berpengaruh signnifikan secara positif terhadap pengelolaan Keuangan

2. Sikap terhadap uang secara parsial atau individu tidak berpengaruh terhadap pengelolaan keuangan

\section{DAFTAR PUSTAKA}

Chintiya M (2010). Pengaruh Locus of Control, Financial Knowladge, dan Income Terhadap Financial Management Behavior. Bandung: Universitas Kristen Maranatha.

Gusta (2010). Analisis Deskriptif Tingka Literasi Keuangan pada UMKM di Pasar Koga Bandar Lampung. Lampung: Universitas Lampung.

Julian (2013). Analisis Tingkat Literasi Keuangan Mahsiswa Fakultas Ekonomi dan IImu Sosial. Riau: Universitas Negri Sultan Syarif Kasim Riau.

Leon, Farah Margaretha (2018). Mengelola Keuangan Pribadi. Jakarta Selatan: Salemba Empat.

Lusardi A, Mitchel (2010). Financial Literacy Among The Young, Jurnal Consumers Affairs. Jilid 44, No.02 (http://onlinelibrary.wiley.com)

Manurung (2009). Succesful Financial Planner A Complite Guide. Jakarta: Grasindo. 


\section{P-ISSN: 2598-5035; E-ISSN: 2684-8244}

Mersa (2017). Pengaruh Literasi Keuangan Terhadap Pengelolaan Keuangan Pribadi pada Mahasiswa. Samarinda: Politeknik Negri Samarinda. Soetiono, Kusumaningtuti S (2017). Mengenal Otoritas Jasa Keuangan dan Lembaga Jasa Keuangan. Jakarta: Otoritas Jasa Keuangan.

Soetiono, Kusumaningtuti S (2018). Literasi dan Inklusi Keuangan Indonesia. Depok: Charisma Putra Utama Offset.

Undang-Undang Hukum Dagang (KUHD) pasal 26. Undang-Undang Otoritas Jasa Keuangan No. 21 Tahun 2011.

Undang-Undang Perbankan No. 10 Tahun 1998.

Vincentius A, Nanik L. (2014). Hubungan Faktor Demografi dan Pengetahuan Keuangan Karyawan Swasta. Surabaya: Universitas Air Langga.

Warsono (2010). Prinsip-prinsip dan praktik keuangan pribadi. Jakarta: Unversitas Indonesia.

Willy (2012). Analisis Pengaruh Literasi Keuangan Terhadap Keputusan Investasi. Palembang; STIE Multi Data Palembang.

Zahruyan (2016). Pengaruh Literasi Keuangan dan Sikap Terhadap Uang pada Perilaku Pengeloalaan Keuangan Keluarga. Surabaya: STIE Perbanas Surabaya 